\title{
Development of Libraries of the Congress of Southeast Asian Librarians (CONSAL): 1996 to 1999
}

\author{
Chin Chuan, Yit( $\left.{ }^{*}\right)$ and Foo, Schubert(**) \\ (*) Product/Services Development, National Library Board, 3 Temasek Avenue \#07-01 Centennial Tower, Singapore \\ 039190 \\ ${ }^{(* *)}$ Division of Information Studies, School of Computer Engineering, Nanyang Avenue, Nanyang Technological \\ University, Singapore 639798
}

\begin{abstract}
The Congress of Southeast Asian Librarians (CONSAL) was formed in 1970 among a number of ASEAN countries with the vision of relationship building, sharing, cooperation and collaboration among member countries in the fields of librarianship, library and information sciences, documentation, information and related activities. In its 30th year since its formation, CONSAL has to date 10 members which includes the library associations and librarians of Brunei, Cambodia, Indonesia, Lao, Malaysia, Myanmar, Philippines, Singapore, Thailand and Vietnam.

CONSAL holds a conference every three years in each member country by turn. As part of traditional proceedings, each member country provides a country report detailing library developments over the previous 3 years. The information reported so far is generally adhoc without any prescribed format or guidelines, with each country volunteering whatever information that is deemed appropriate. This paper reports a questionnaire survey that was administered to all CONSAL members just before the CONSAL XI conference in an attempt to collect a uniform set of statistics to report on the library developments in the region as a collective whole for the 4 year period from 1996 to 1999. The questionnaire design, findings and discussion of the survey data along with a number of recommendations for future CONSAL work is presented.
\end{abstract}

Keywords: CONSAL, ASEAN, library development, questionnaire survey

\section{Introduction}

CONSAL (Congress of Southeast Asian Librarians) have entered its 30th year of existence since its inauguration in 1970 (CONSAL I, 1970). It was formed as a response to a growing sense of regional or Southeast Asian identity, fostered particularly by the formation of the Association of Southeast Asian Nations (ASEAN). It currently comprises the member countries from Brunei, Burma, Cambodia, Indonesia, Laos, Malaysia, Philippines, Singapore, Thailand and Vietnam (CONSAL, 2001a). Its objectives are to establish and strengthen relations among librarians, libraries, library schools, library associations and related organizations in the region, to promote cooperation in the fields of librarianship, library and information sciences, documentation, information and related activities in the region, and to co-operate with other regional and international organizations and institutions in the similar fields and activities (CONSAL, 2001b)

As part of CONSAL activities, it holds a conference once in every three years in each member country by turn and aims to promotes cooperation in the fields of librarianship, bibliography, documentation and related activities in the region. Membership to CONSAL is open to librarians, library schools, library associations and related organizations in the region (Khoo, 1996).

Activities for CONSAL are funded through the support of international organizational foundations, governments and firms within the region as well as organizations outside the region, including UNESCO, IFLA, the Commonwealth Foundation and the National Library of Australia as well as other various fund-raising activities.

The last CONSAL conference, CONSAL XI with the theme of "Challenges for Library and Information Professionals" was held in Singapore in 2000 (CONSAL XI, 2000). It is also traditional in such conferences for individual member countries to present a report of the country's activities. As part of the preparation for CONSAL XI, a survey was conducted to access the changes and development that have occurred between 1996 to 1999 across member countries since the last meeting in Malaysia (CONSAL X, 1995).

This paper presents the survey methodology, findings, and assesses the 8 main areas of library development in these countries, namely, physical, standards, system, staff, collection, user, research and special development. As different libraries would be tracking their own development processes with varying emphasis and criteria, it is not the intention of this study to uncover or highlight differences between the countries but to provide a collective view and update of the libraries of CONSAL. As such, the results are normalized wherever possible to minimize country-to-country differences, and combined so that it could be taken as a representative whole of these regional libraries. In addition, it is proposed that the study questionnaire, after some modification as a result of this study, could be used as a basis for developing a unifying framework for the collection of standard library statistics in these countries so that a true and more representative collective picture of the libraries of CONSAL can emerge in future.

\section{Methodology}


A questionnaire survey was used to collect the main source of data for the study. The survey method was primarily chosen as it was the quickest form to obtain responses from the respondents in these various countries since there are no available funding from CONSAL for the study to be conducted in individual countries. In addition, a literature review of publications covering library matters pertaining to Southeast Asia was also conducted with the aim of ascertaining the level of research activity and interest within and outside these ASEAN countries. Such research activity was seen as a broad indicator of proficiency and interest in library activities in the region.

The questionnaire was divided into 8 main sections pertaining to 8 main areas of library development:

Part 1 Physical Development

Part 2 Standards Development

Part 3 Systems Development

Part 4 Staff Development

Part 5 Collection Development

Part 6 User Development

Part 7 Research Development

Part 8 Special Development

Appendix 1 shows a condensed form of the original questionnaire with all the relevant details. Tables are used extensively in the questionnaire to record responses.

\section{Physical Development}

This relates to the physical development of libraries in the countries in terms of types, numbers, sizes and locations. Changes in the numbers provide an indication of the country's effort in developing new physical libraries (Table1.1). Changes in the size and floor space allocation in libraries that incorporate the built-up area, shelves, storage, office and public areas were used to track changing library priorities and focus (Table1.2). The location and distribution of national and public libraries in contrast to the population centres it serves provides supporting information in the physical development of libraries in the country (Table1.3).

\section{Standards Development}

This relates to forms of library and information standards that were used in the library in various areas of library work including the use of bilbliographic tools, classification schemes, forms of catalogues, information exchange with other parties, and other forms of standards (Table2.1). Thus, this section provides an indication of the common and differing standards used by the libraries of CONSAL thereby highlighting movements towards convergence or divergence in the standards used.

\section{Systems Development}

This relates to the different types of systems that were employed by libraries to perform its main functions of acquisition, cataloging and circulation work (Table3.1). Such systems can be fully automated, semi-automated or still carried out via manual work. In addition, it assesses the use of integrated systems and availability of networks to link to other libraries within the country, or outside the country. The level of automation achieved by the libraries in the region can thus be inferred from this section of the questionnaire. Additionally, this knowledge along the standards knowledge will be useful to CONSAL members in identifying the means for information exchange and collaborative work.

\section{Staff Development}

This relates to staffing of libraries to enable a profile of staff information be obtained. This includes the number of trained professionals holding various administrative positions (Table4.1), their training background (Table4.2), the length of service (Table4.3), work roles (Table4.4) and their involvement with staff attachments, professional visits and conferences (Table4.5). Such information will allow trends in staff development to be identified thereby leading to a clearer picture of the changes that are occurring in the librarians' work in the region.

\section{Collection Development}

This relates to the collection development of the libraries and attempts to discover changes in the volumes and makeup of the materials collected by the libraries. It examines the state of deposits of national publications in various forms and formats (Table5.1), the collection mix in the library via a breakdown by language, by age group, by accessibility and by subject areas (Tables 5.2 to 5.5 ). Such information will enable changes in the emphasis of libraries to support information needs of the users within the region to be identified.

\section{User Development}

This relates to the more traditional library performance indicators used in most libraries to gauge its effectiveness in terms of membership and loans (Tables 6.1 and 6.2), enquiries handled (Table 6.3), user feedback (Table 6.4) and user education and programs (Table 6.5). Such information would help assess if demand for libraries is changing and if there are trends of improvement or degradation in services.

\section{Research Development}

This relates to the level of professional and research activities that are carried out by librarians in terms user studies (Table7.1) and the production of library-related publications in various forms and outlets (Table7.2). Such information provides an indication of the activity level in terms of research in this region and the extent in which these findings are 
shared with the community at large.

\section{Special Development}

This relates to special activities, events or projects that are carried out by the libraries during the period of study. This section of the questionnaire allows the respondent to highlight and report such related information that would be of interest to other CONSAL members.

\section{top of page}

\section{Findings}

The survey was sent to all the 10 representative country members from the CONSAL XI Executive Board on 29 September 1999 through the Honorary Secretary of the Board. Each member, who acted as coordinator for the collection of data, was given approximately 4 weeks to file the returns. Returns were obtained from 7 out the 10 countries. Of the 3 non-responding countries, one of them have given feedback that the statistics required were too detailed and that they could not provide the information required within the survey timeframe.

Returns were received from the Universiti Brunei Darussalam Library (UBD), National Library of Laos (NLL), the Perpustakaan Negara Malaysia (PNM), National Library of Myanmar (NLM), the Universities Central Library of Myanmar (UCL), National Library Board of Singapore (NLB), National Library of Vietnam (NLV) and five academic libraries from the Philippines, namely, De La Salle University Library (DLSU), Visayas State College of Agriculture Library (VSCA), Aklatang Emilio Aguinaldo Library (AEA), Xavier University Libraries (XU) and Cor Jesu College of Digos Library (CJCD). These returns were primarily from the national libraries of the representative country members except for the Philippines. These country members who were basically from the national libraries of their respective countries were requested to participate in the survey as well as disseminate and collate the survey returns from other types of libraries in the country. This explains the mix of returns that were received from the survey. All returns received were incomplete in various parts of the survey.

The incompleteness of the data arose due to the comprehensive nature of the required statistics over the 4-year time frame, the lack of collection of such statistics in respondents' libraries, and the limited allocated time for data collection and collation. In order to supplement the missing bits of information and enable a basis for comparison of changes monitored, additional information were extracted from the UNESCO statistical yearbook (UNESCO, 1998), United Nations Statistical yearbook (United Nations, 1998) and the World of Learning (1999) and presented in the findings. Such data are clearly indicated whenever they are used.

Of the 7 responses received, Brunei's response was from an individual academic library (UBD) and therefore cannot be to taken to be representative of the development of libraries within the country itself. With the absence of returns from Indonesia and Thailand, the findings cannot be therefore be interpreted as a true reflection but as a general indication of library developments in the region. In addition, no findings were reported for sections of the survey where the data returns were particularly thin or lacking from the respondents.

\section{Physical Development}

Table 1. Changes in the total number of libraries (national and public) within the region

\begin{tabular}{|l|l|l|l|l|l|}
\hline Country & 1995 & 1996 & 1997 & 1998 & 1999 \\
\hline Brunei & $5^{*}$ & 5 & 5 & 5 & 5 \\
\hline Cambodia & NA & NA & NA & NA & NA \\
\hline Indonesia & NA & NA & NA & $23 \#$ & 23 \\
\hline Laos & NA & 12 & 19 & 19 & 19 \\
\hline Malaysia & $545^{*}$ & 545 & 624 & 666 & 666 \\
\hline Myanmar & $2^{*}$ & 2 & 2 & 2 & 2 \\
\hline Philippines & $4^{*}$ & 4 & 4 & 4 & 4 \\
\hline Singapore & $22^{*}$ & 29 & 40 & 54 & 58 \\
\hline Thailand & $614^{*}$ & 614 & 614 & 614 & 614 \\
\hline Vietnam & $566^{*}$ & 2429 & 2435 & 2539 & 2803 \\
\hline CONSAL & 1758 & 3640 & 3743 & 3926 & 4194 \\
\hline \%/1995 base year & $100 \%$ & $207 \%$ & $213 \%$ & $223 \%$ & $239 \%$ \\
\hline \%/1996 base year & - & $100 \%$ & $103 \%$ & $108 \%$ & $115 \%$ \\
\hline
\end{tabular}

* Figures from (UNESCO, 1998) \# Figures counted from (The World of Learning, 1999, pp 738-740) Figures for subsequent years were assumed to be unchanged to the previous years if no new reports were received from countries.

Table 1 shows the changes in the total number of national and public libraries in the region. Although the original survey attempted to collect data with regards to the total number of libraries to include all types of libraries, figures for 
school and other libraries were subsequently omitted in the presentation. This was so since due to the large number of school libraries (in excess of ten thousand) reported by some countries thereby making the figures for national libraries and public libraries insignificant for comparison across the years. In addition, other variety of libraries was also omitted as they were no consistent trends in reporting.

As the survey also faced problems in receiving new data, it was assumed that changes subsequent to the earliest known reported figures for each country would not have changed significantly from the last known reported data. Figures for Thailand and Indonesia were extracted from sources external to the survey. Figures for Cambodia could not be determined. From the results, it can be seen that there was an increase in the number of libraries accessible to the people living within the region over the tracked period that averages to an annual growth rate of approximately $5 \%$.

When comparing the percentage of physical growth of libraries to changes in population trends which grew an average 2.3\% per annum in the region 1987 to 1997 (United Nations, 1998), it becomes apparent that libraries appeared to be developed at a faster rate than the increase in population. This could be indicative of the willingness of the respective funding bodies to invest into more libraries to enable their citizenry better opportunity of establishing themselves and keeping pace with the information age.

top of page

\section{Standard Development}

Table 2: Percentage of libraries adopting specific standards

\begin{tabular}{|c|c|c|c|c|}
\hline Aspect of Library Work & 1996 & 1997 & 1998 & 1999 \\
\hline \multicolumn{5}{|l|}{ Bibliographic: } \\
\hline AACR & $100 \%$ & $100 \%$ & $90 \%$ & $80 \%$ \\
\hline LCSH & $57 \%$ & $57 \%$ & $57 \%$ & $57 \%$ \\
\hline Others: & & & $10 \%$ & $17 \%$ \\
\hline \multicolumn{5}{|l|}{ Classification: } \\
\hline DDC & $67 \%$ & $67 \%$ & $61 \%$ & $54 \%$ \\
\hline LC & $50 \%$ & $50 \%$ & $43 \%$ & $38 \%$ \\
\hline \multicolumn{5}{|l|}{ UDC } \\
\hline Subject & & & $3 \%$ & $3 \%$ \\
\hline Others & & & & $11 \%$ \\
\hline \multicolumn{5}{|l|}{ Forms of Catalogs: } \\
\hline Book & $14 \%$ & $14 \%$ & $10 \%$ & $10 \%$ \\
\hline Card & $57 \%$ & $57 \%$ & $41 \%$ & $45 \%$ \\
\hline Microform & & & & $1 \%$ \\
\hline Electronic & $57 \%$ & $57 \%$ & $50 \%$ & $58 \%$ \\
\hline
\end{tabular}

Data based on returns by Laos (1998-99), Myanmar, Philippines, Singapore, Vietnam (1999).

Table 2 shows the percentage of libraries of CONSAL adopting various standards in different aspects of library work. In most instances, each country or library would have endorsed specific standards fully $(100 \%)$. Exceptions were observed for Laos and Vietnam where they required special standards to be used for some of their special collections. 
Overall, it could be observed that AACR remain a popular standard within the libraries surveyed. DDC appear to be on the decline but remained as the most popular classification tool in use by the libraries. It could also be seen that the development of electronic form of catalogs had not changed significantly over the tracked period.

top of page

\section{System Development}

Table 3: Changes of operating system within CONSAL

\begin{tabular}{|c|c|c|c|c|}
\hline Type of Library Operating System & 1996 & 1997 & 1998 & 1999 \\
\hline \multicolumn{5}{|l|}{ Acquisition } \\
\hline Manual & $60 \%$ & $40 \%$ & $40 \%$ & $49 \%$ \\
\hline Semi-automated & $40 \%$ & $60 \%$ & $60 \%$ & $39 \%$ \\
\hline Automated & & & & $13 \%$ \\
\hline \multicolumn{5}{|l|}{ Cataloging } \\
\hline Manual & $33 \%$ & $17 \%$ & $17 \%$ & $21 \%$ \\
\hline Semi-automated & $33 \%$ & $50 \%$ & $33 \%$ & $45 \%$ \\
\hline Automated & $33 \%$ & $33 \%$ & $50 \%$ & $33 \%$ \\
\hline \multicolumn{5}{|l|}{ Circulation } \\
\hline Manual & $80 \%$ & $60 \%$ & $60 \%$ & $63 \%$ \\
\hline Semi-automated & & & & $13 \%$ \\
\hline Automated & $20 \%$ & $40 \%$ & $40 \%$ & $25 \%$ \\
\hline
\end{tabular}

Table 3 shows the changes of the types of operating systems used in the major functions of library work. The data in the Table was based on responses from Vietnam, Laos, Philippines, Myanmar and Singapore. The results showed that a general decrease in the use of manual systems and a gradual shift towards automation. The figures for 1999 appeared to have bucked the general trend, but this was largely due to the introduction of a figure from one country (AEA) that did not report figures for the previous years.

top of page

\section{Staff Development}

Table 4: Number of employed staff (breakdown by training)

\begin{tabular}{|c|l|l|l|l|l|}
\hline Staff Position & 1996 & 1997 & 1998 & 1999 \\
\hline Directors and above & 21 & 22 & 22 & 22 \\
\hline Library Professional & 10 & 12 & 14 & 14 \\
\hline Non-Library Professional & & & & \\
\hline Managers and above & 74 & 56 & 63 & 66 \\
\hline Library Professional & & & & & \\
\hline
\end{tabular}




\begin{tabular}{|c|l|l|l|l|}
\hline Non-Library Professional & 16 & 16 & 21 & 25 \\
\hline Librarians or Library Executive Officers & & & & \\
\hline Library Professional & 250 & 311 & 321 & 324 \\
\hline Non-Library Professional & 29 & 42 & 65 & 63 \\
\hline Library Support Staff & & & & \\
\hline Para-Professional & 216 & 225 & 368 & 370 \\
\hline Non-Professional & 230 & 226 & 215 & 208 \\
\hline Other Staff Types & & & & \\
\hline Library Professional & 66 & 74 & 125 & 133 \\
\hline Non-Library Professional & & 181 & 183 \\
\hline
\end{tabular}

Data based on returns by Brunei, Laos, Myanmar, Singapore, Vietnam

Table 4 shows the breakdown of the number of staff based on the appointments within the libraries. The results showed that there were little changes for librarians assuming the post of Director. More non-library professionals took up senior positions within these libraries. Directors represent the senior management of the libraries while Managers represent the middle operating management of the libraries. While little changes to the number of managerial positions were observed, the trend of more non-library professionals joining the service could be seen. Visible changes were seen in the junior positions with an increased of about $30 \%$ or more in the number of posts. It could also be observed that there was a gradual decrease in the number of non-trained staff for the Library Support Staff position yearly.

Table 5: Number of staff (breakdown by place of training)

\begin{tabular}{|c|c|c|c|c|}
\hline Staff Type & 1996 & 1997 & 1998 & 1999 \\
\hline \multicolumn{5}{|l|}{ Professional } \\
\hline Local & 17 & 486 & 961 & 208 \\
\hline SEA (exclude Local) & & & 1 & 2 \\
\hline ASIA (exclude SEA) & 2 & 3 & 2 & 4 \\
\hline AMERICA & 2 & 1 & 6 & \\
\hline EUROPE & 2 & 6 & 1 & 1 \\
\hline \multicolumn{5}{|l|}{ Para-Professional } \\
\hline Local & 70 & 72 & 74 & 83 \\
\hline \multicolumn{5}{|l|}{ Support Staff } \\
\hline Local & 75 & 490 & 570 & 466 \\
\hline SEA (exclude Local) & & & & 30 \\
\hline OCEANA & & & & 1 \\
\hline
\end{tabular}


Data based on returns by Brunei, Laos, Myanmar,Vietnam

Table 5 shows the library staff breakdown by place of training. It can be seen that the majority of staff in libraries of CONSAL was still largely locally trained. The figures also indicate that there are no significant trends of any increase in the attraction of foreign talents in the region for library work.

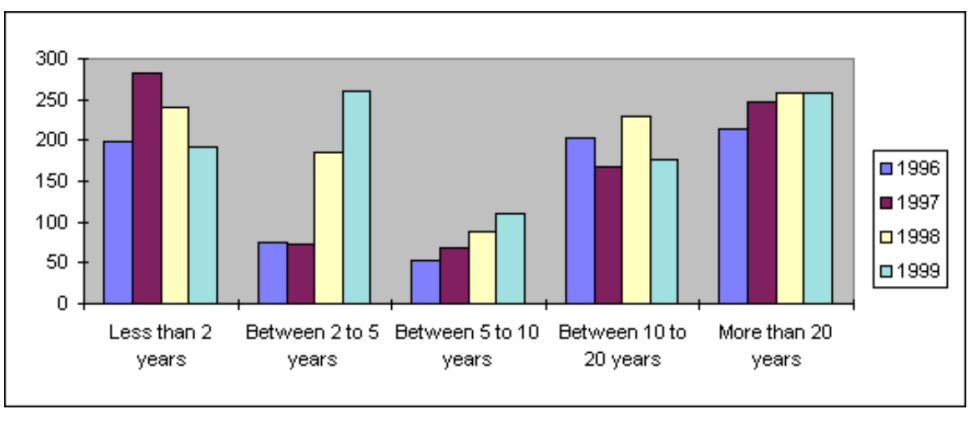

Figure 1: Breakdown on the years of service of library staff

Figure 1 shows the trend in the relative years of service of employed library workers. A V-shaped contour, or valley, is apparent over the continuum of years of service. There appeared to be fewest workers between the 5 to 10 year range and that most of the library staff were composed of staff who have either worked for a long time, or are relatively new staff joining the library. However, an upward trend of staff numbers within this 5 to 10 year group over the tracked period is noted.

top of page

\section{Collection Development}

Table 6: Percentage deposition of National Publications

\begin{tabular}{|c|l|l|l|l|l|}
\hline Type of publication & 1996 & 1997 & 1998 & 1999 \\
\hline Print & 83.3 & 81.3 & 85 & 80.3 \\
\hline Books & 87.8 & 93.3 & 93.3 & 89.1 \\
\hline Periodicals & 42.9 & 45.3 & 41.4 & 43.1 \\
\hline Others: & & & & \\
\hline Non-Print & & & & \\
\hline Audio-visuals & & & & \\
\hline Digital or Web-based & & & & \\
\hline Others: & & & & \\
\hline
\end{tabular}

Data based on returns by Brunei, Malaysia, Laos, Vietnam

Table 6 shows the percentage deposition of National Publications. No significant changes in trends were observed. As one would expect, no complete success was reported for implementation of national depository policies. The result was particularly poor in the area of non-print format with a value of below $5 \%$.

The results for the total number of collections for libraries of CONSAL could not be consolidated due to the fragmented data provided by respondents. Only Brunei (UBD) and Singapore (NLB) provided figures that could be tracked over the years. The changes in total collection for the national and public libraries in these countries are shown in Table 7.

Table 7: Changes in total collection in National and Public Libraries

\begin{tabular}{|l|l|l|l|l|l|}
\hline Country & 1995 & 1996 & 1997 & 1998 & 1999 \\
\hline Brunei & $285,000(100 \%)$ & $349,731(123 \%)$ & $362,866(127 \%)$ & $372,013(131 \%)$ & $353,895(124 \%)$ \\
\hline
\end{tabular}


Data based on returns by Brunei and Singapore

It is apparent from the Table 7 that there was a steady increase of collection size over the years from the libraries of Brunei and Singapore. The rate of increase was different for each of the library. Figures for Brunei showed a decrease in 1999. This could be attributed to the library carrying out a weeding exercise. As only two members returns were used for Table 7, no conclusive observations can be inferred for the CONSAL libraries as a whole.

top of page

User Development

Table 8: Changes in Loans per member (LPM)

\begin{tabular}{|l|l|l|l|l|}
\hline Country & 1996 & 1997 & 1998 & 1999 \\
\hline SingaporeRegistered membersLPM & $1,202,58715.7$ & $1,360,68016.3$ & $1,595,20515.4$ & $1,774,30015.9$ \\
\hline MalaysiaRegistered membersLPM & $43,2896.2$ & $46,5126.8$ & $77,3575.0$ & $57,2615.6$ \\
\hline VietnamRegistered membersLPM & $5,93936.7$ & $5,62542.7$ & $7,11747.2$ & $6,66542.8$ \\
\hline Average LPM values & 19.5 & 21.9 & 22.5 & 21.4 \\
\hline
\end{tabular}

Table 8 shows the changes in loans per member in Malaysia, Singapore and Vietnam.

The loan per member (LPM) figure was normalised by dividing the total loans with the number of registered members. The LPM was then averaged to track changes across the years for the respondent libraries. No significant changes occurred within the years for these countries. The largest difference in value of 22.5 to 19.5 constituted about $15 \%$ difference based on 19.5 value as the base figure.

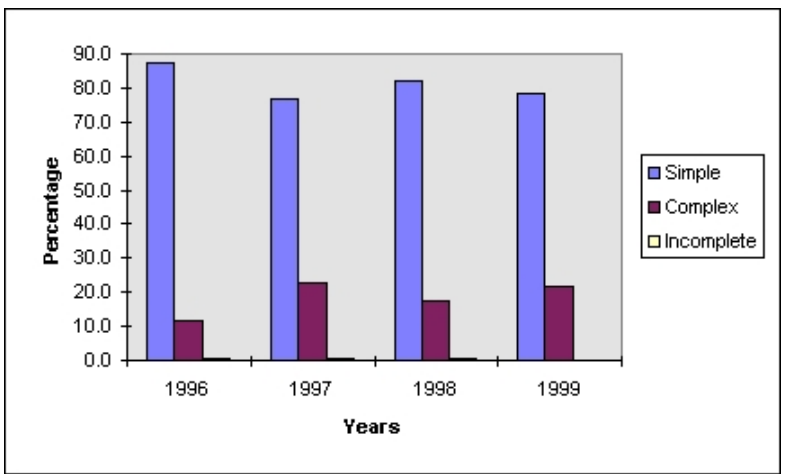

Figure 2: Types of User Enquiries

Data based on returns by Brunei, Malaysia, Myanmar, Singapore, Vietnam

Figure 2 shows the percentage of the different types of user enquiries. It is evident that there was still a large amount of directional or simple enquiries being made by users at the libraries. Libraries were also largely effective in the handling of user enquiries as the incidence of incomplete answers to enquiries were very low $(<1 \%)$ throughout the years.

top of page

\section{Research Development}

Table 9: Number of user studies conducted

\begin{tabular}{|l|l|l|l|l|}
\hline & 1996 & 1997 & 1998 & 1999 \\
\hline Number of User Studies conducted in & 682 & 1029 & 159 & 252 \\
\hline$\%$ change/1996 base year & 100 & 150.8 & 23.3 & 36.9 \\
\hline
\end{tabular}

Data based on returns by Brunei, Laos, Malaysia, Philippines, Singapore, Vietnam

Table 9 shows the total number of user studies that have been conducted over the tracked period. User studies in this context includes surveys, statistical analysis, interviews, focus group sessions and passive observations. The results indicated a peak interest in 1997, a big dip in 1998 and a resurgent of activities in 1999. The peak in 1997 could possibly be attributed to preparations for the 1998 IFLA meeting in the region.

Table 10: Library-related publications 


\begin{tabular}{|l|l|l|l|l|l|}
\hline Type of publication & 1996 & 1997 & 1998 & 1999 \\
\hline Published papers & 13 & 18 & 17 & 16 \\
\hline Thesis & 3 & - & 2 & 6 \\
\hline Books & 10 & 18 & 13 & 5 \\
\hline Periodicals & 10 & 14 & 13 & 6 \\
\hline Internal Reports & 44 & 109 & 71 & 30 \\
\hline Digital or Web-based products & - & - & 14 & 6 \\
\hline Others (please specify): & & & & \\
\hline Comprehensive Bibliography & 3 & 3 & 2 & 2 \\
\hline CD-ROM & 2 & & & \\
\hline Audio-books & 10 & & & \\
\hline Videos & 3 & & & \\
\hline Handbooks/guides & 8 & 9 & 16 & 17 \\
\hline Newsletters & 11 & 11 & 11 & 11 \\
\hline Total & 117 & 182 & 159 & 99 \\
\hline
\end{tabular}

Data based on returns by Laos, Malaysia, Philippines, Singapore, Vietnam

Table 10 shows the various forms of publications produced by libraries. The non-print format was used up till about 1996. This was replaced by the emergence of Web-based products from 1998. The number of publications appears to peak in 1997 that coincided with the trend displayed in user studies. It was likely that the users studies conducted during this time gave rise to proportional increases in publications. Publication activities appeared to have tapered off after 1997 and there was a subsequent decline in overall publication figures.

\section{top of page}

\section{Special Development}

As part of the survey, respondents were invited to outline special projects or developments that took place in their countries during the period. Five respondent libraries provided information on this aspect (Yit, 2000).

PNM (Malaysia) reported the initiation of the Connected Learning Community project in 1998. This project was a collaboration of Microsoft (Malaysia), MIMOS Berhad and the state libraries. A Connected Learning House (CLH) website was established to provide information as well as serve as a platform for the exchange of information between students, teachers, parents and the public using the Internet (PNM, 2001).

NLB (Singapore) reported a number of various programs and special projects. In 1996, two new projects were initiated: the Reference Point (NLB, 2001) and Shopping Mall Libraries. Reference Point was started to serve as a centralized reference enquiry service to its users through telephone, fax, normal and electronic mail and web platforms. Shopping Mall Libraries were started in 1996 with Jurong West Community Library as its first library sited within a commercial shopping mall. This was in line with NLB's aim of bringing access to and improving convenience for its users.

In 1997, self-checkout machines were made available to NLB users. This project was done to save user time and has been shown to reduce the queue at NLB libraries. The project started with $3 \mathrm{M}$ machine, but in 1998, trials with a new technology based on Radio Frequency was initiated and the self-checkout service has been improved to the extent where users were not required to open their books for the machines to detect the material borrowed.

By 1998 NLB has embarked on 2 more projects: Electronic Services and Virtual Communities. The National Computer Board of Singapore (now known as InfoComm Development Authority of Singapore) completed a national broad-band information infrastructure known as Singapore One. This enabled more advanced applications to be supported on the Web within Singapore and NLB used the platform to start various electronic based services like video-on-demand, online database access, shared use of CD-ROM and web-casting. A first Virtual Community project, namely, the Student Virtual Community was established. This project had similar objectives to that of the Connected Learning Community Project initiated by PNM.

In 1999, NLB embarked on another 2 projects called Customized Information Service (CIS) and Cybrarian Service. The CIS can be viewed as an extension of the Reference Point project with implementation of customization to user needs. As such, user account management with regards to service, product and information organization would be handled through a subscription to a centralized information management unit. Cybrarians, a new term coined as a combination of the Cyber-age Librarians, were created to support on-line web request and service customers who require assistance on the web. Users have visual contact with a librarian at a remote site through video-conferencing facilities to allow them to communicate better with the librarians.

In 1999, NLB embarked on a massive over-haul of its data management system shifting from its traditional URICA-based system to a CARL-based system. The implementation for the new system was still on-going at the time 
when the survey was compiled.

NLL (Laos) reported the progress of the "Preservation of LAO Palm Leaf Manuscripts Program", a project scheduled to run from 1992 to 2002 in co-operation with Germany. The main aim of the project was to develop human resource for LAO to be handle future needs of the information protection of LAO studies. Another LAO-Germany project, "Archives of Traditional Music in Laos/Internal Systemalization of Traditional Music In Laos" project was initiated in 1999. These two projects were closely related to the activities reported by Abhakorn (1997) that involved Laos, Myanmar and Thailand to set up a collective memory of Mainland Southeast Asia. NLL also planned for a millennium project targeted for 2001 to 2005 to set up a shared database resource that would be made available to CONSAL countries provided funding could be obtained.

DLSU (Philippines) reported the completion of the Theses Database Sharing Program that was carried out during 1996 to 1997 which comprised 5 participating academic institutions within the Philippines. This project allowed electronic access to the bibliographic details of all theses up to 1995 within these institutions. This project was extended to a subsequent Theses Database Sharing Project that ran from 1997 to 1998 in which access to the bibliographic details of theses up to 1994 that were submitted to the Department of Education was achieved.

DLSU had also embarked on a "Full-Text Online Access to Electronic Literature" project from 1998 to 1999. Through this, access via OCLC FirstSearch service was arranged to obtain full-text information of periodical literature that were electronically published. The "Digitization of Rare Filipiniana Books 1998-1999" project saw selected valuable materials from five academic institutions covering rare Filipiniana collections digitized in an attempt to preserve the information content of these collections. DLSU also participated in an 8 institution tie up to form the DOST-ESEP network which linked acquisition of library materials as well as facilitated access to all collections within these institutions.

XU (Philippines) reported the formation of ALINET (Academic Libraries Information Network in Mindanao) in 1997 that involved 26 member libraries in Mindanao. This project allowed shared access to a database of theses and Filipiniana collection within the network.

VSCA (Philippines) reported the setting up of SEARCA Knowledge Network (or K-Net) in 1999. This special database was set up to provide strategic information for agricultural management.

top of page

\section{Discussion}

From the presented findings, a number of specific trends and changes were readily apparent between 1996 and 1999. Some of these are examined in this section and a number of issues are identified that can serve as potential future work for libraries of CONSAL.

\section{Physical Development}

The physical growth of the libraries in the region increased at a slow steady pace. Although the libraries have on the whole not hit the plateau or optimal level for physical development, it is likely that they are getting quite close to it. This assumes that countries of CONSAL have similar objectives and financial commitments to develop libraries as part of the national drive in the new information age. The new issue facing CONSAL is not about building more libraries, but to tackle the issue of the Internet. While it cannot be argued that there would always be demand for physical items and materials to be present, the capability of the Internet to provide faster and multiple access to information resources cannot be ignored. Thus, libraries have to be prepared to adopt the role of maintaining and managing hybrid libraries and ensure both physical and non-physical sites complement each other. This is necessary to avoid been left behind in terms of the provision of library services in comparison to the more developed Western counterparts (Mesher, 1996).

The running of non-physical sites would not be easy and pose special problems in auditing and physical accounting of assets owned by libraries. As such, it would often be difficult for libraries to procure funding and support that is needed for startup investments. A possible solution is for all libraries of CONSAL to collaborate and pool their resources together to provide such a service that could be accessible by all countries in the region.

\section{Standard Development}

There do not appear to be much change in the development of electronic catalogs within the libraries. This is one aspect of standards that could be consolidated in CONSAL so that some form of move towards electronic catalogs can take place. A set of agreed information exchange standards could be adopted to support the exchange of bibliographic information to provide the potential access and sharing of each other's collection in future. Likewise, some form of exchange of information and technology can take place to close the gap between the different practices adopted by different countries.

\section{System Development}

A slow but steady move towards full automation in most libraries of CONSAL was observed. Libraries appeared to initiate their automation efforts mainly in their cataloging first before shifting their efforts to acquisition and circulation. 
The knowledge gained by libraries that have gone into full automation can be shared with those libraries that have just embarked upon automation. This is an opportunity through which assistance could be provided by the more knowledgeable libraries to those who lack the experience.

\section{Staff Development}

The findings indicated that more non-library professionals have stepped into the fray of managing libraries. This could be indicative that libraries have moved into a new era where the parties with vested interest actively come into the arena of this information industry and position themselves at authority levels to achieve expected outcomes. Such changes should be welcomed as they bring new perspectives and insights to the operational ground rules of the library profession.

The staffing of libraries of CONSAL showed that these libraries were not really going beyond the region shores to actively recruit and retain the services of library professionals from abroad. This may be due to financial constraints in libraries or a factor of attractiveness to work in the region to potential expatriates. Bringing in foreign talents can yield many advantages and is an area that can be reviewed among CONSAL members.

Libraries of CONSAL also appear to suffer from a "middle-bare" syndrome as shown in Figure 1. There appears to be fewer staff worked in libraries continuously between the band of 5 to 10 years. Ideally, libraries should attain a steady state of similar percentages for all age groups among staff. Having this lack of staff in this band can give rise to potential problems, such as sharing of corporate ideals, between those who have worked for a long time and those who have newly joined the service. Such a bridge between "old" and "new" staff is important in many instances. Such staff tends to be at their prime, thereby operationally productive, and can serve as good channels to promote library development plans and play important roles to win staff buy-ins in implementing new ideas. Nonetheless, it is recognised that these are just suggestions of potential problems that may never even exist in the face of a sound and good library management showing the right qualities of leadership, rewards, motivation, structure, learning, training and culture.

\section{Collection Development}

Difficulties were faced with the collection of such data from various libraries. A special committee may be initiated by CONSAL to co-ordinate the collection such statistics and assist those countries who have difficulties acquiring such information. Having such a set of statistics would reveal a clear picture of the collective information assets, that in turn will provide an opportunity to the libraries of CONSAL to negotiate among member countries and other external bodies for future cooperative efforts.

It is also observed that the deposition patterns of local information materials in the libraries of CONSAL have not undergone much change over the tracked period. As it is important for the libraries to acquire and maintain this aspect of information and national heritage in their collection, CONSAL can embark upon a collaborative promotional effort to encourage the deposition of all information materials within each country.

\section{User Development}

User habits in terms of Loan Per Membership (Table 8) remained consistent across the years with their member reading an average of 2 books per month. Depending on the desired outcomes among the libraries of CONSAL, some form of reading promotion may be desirable to bring up this value in future.

Little changes to the types of enquiries handled by the libraries of CONSAL was also evident (Figure 2). References services were mainly utilised for simple enquiries. In order to reduce this problem in future, some initiatives to improve the proper usage of the reference services through self-help mechanisms may be considered. This will in turn free the reference service to handle more information intensive enquiries.

\section{Research Development}

A flurry of research activities seemed to have occurred in 1997. As suggested previously, this could be a result of the preparations for the 1998 IFLA conference. Total library publications rose during these two years with the majority of publications resulting from internal reports (Table 10). However, not much change was observed in terms of journal publications. CONSAL could potentially play an important contributory role in promoting a research culture within the region. A formation of a CONSAL international journal may be initiated to concentrate on publishing library-related research activities pertaining to the region. This will provide an opportunity to promote the libraries of CONSAL within the region as well as the rest of the world.

The libraries of CONSAL appeared to have cut down on the production of non-print materials such as videos and CD-ROM and kept up with the emerging and preferred trend of Web publications as the main avenue for information dissemination. In this respect, there is potential for CONSAL to step in as a regional authority to introduce standards for web publications that could lead to better archival, retrieval and promotion of research articles on the Internet as a whole. A CONSAL consolidated portal for access to web publications within our region could also be set up to facilitate a one-stop access point for regional information.

top of page

\section{Refinement of Questionnaire for Future Data Collection}


Through the experience gained in this study, the questionnaire can be refined and used as the basis for the systematic and consistent means for data collection among CONSAL libraries. The areas that posed special problems for some respondent libraries are also highlighted in the questionnaire (see Appendix). These can be eliminated or redeveloped. Additional instructions and interpretation for data collection can also be included or made more explicit.

As the libraries did not have a coordinated and agreed framework for data collection previously, information and statistics reported previously by different countries were largely individualistic without any datum or baseline to enable a meaningful and accurate picture of library developments for the whole region to be consolidated and presented. CONSAL can therefore take this opportunity to work out such a framework and set up a Web-based coordinating base for collecting such statistics in future. The availability of timely and accurate information based on a consistent mode of collection and interpretation would be most useful and welcomed by all who are interested in such information.

top of page

\section{Conclusions}

A survey using the questionnaire technique was administered to the libraries of CONSAL in an attempt to obtain a set of useful statistics to keep track of the development of ASEAN libraries for the 1996-1998 period that spanned between the CONSAL $X$ and CONSAL XI meetings. Data for 8 main areas of library development were collected, presented and analysed. A collective view and update of library activities along these dimensions together with recommendations for future CONSAL work were highlighted as a result of these findings.

With the arrival of the new millennium, it is timely for CONSAL to take stock of past activities, and envisage its next lap of progress to help develop all participating libraries as a collective whole in attaining its vision of collaborative sharing and cooperation. Many such potential areas have been identified and much remains to be done in CONSAL to bring it to the forefront of library achievements.

top of page

\section{References}

Abhakorn, R. (1997). Towards a collective memory of Mainland Southeast Asia: Field of preservation of traditional manuscripts in Thailand, Laos and Myanmar, IFLA Journal, 23(2), 107-111.

CONSAL (2001a). About CONSAL: History, Available: http://www.consal.org.sg/about/history.asp

CONSAL (2001b). CONSAL Constitution, Available: http://www.consal.org.sg/constitution/name.asp

CONSAL I (1970). New prospects for Southeast Asians cooperation, 1st Congress of Southeast Asian librarians, Singapore.

CONSAL X (1995). Libraries in national development, 10th Congress of Southeast Asian librarians, Malaysia.

CONSAL XI (2000). Challenges for Library and Information Professionals, 11th Congress of Southeast Asian librarians, Singapore. Also available: http://www.consal.org.sg (April 2001)

Khoo, S.M. (1996) Memorable journey: commemorating 25 years of CONSAL (Congress of Southeast Asian Librarians), in Library in national development: Papers and proceedings of the 10th CONSAL, Kuala Lumpur, Malaysia: University of Malaya Library.

National Library Board, (2001). NL.Line: Reference Point, Singapore, Available: Available: http://www.lib.gov.sg /services/refpoint/refpoint.html (April 2001)

Mesher, G. (1996). The Internet in Asia. Modern countries move ahead, Internet World, December, 56-57.

Perpustakaan Negara Malaysia, (2001). Connected Learning House website, Available: http://www.clh.com.my /home.asp (April 2001)

United Nations Educational, Scientific and Cultural Organization (UNESCO), (1998). "Libraries by category" in UNESCO 1998 Statistical Yearbook. Bernan Press, USA. Chap 7.1, 7.10-7.11.

United Nations (1998). Statistical Yearbook for Asia and the Pacific 1998. United Nations, Bangkok, Thailand. (Brunei Darussalam: 91-100; Cambodia-Cambodge: 102-108; Indonesia-Indonesie: 200-215; Lao People Democratic Republic - Republique Democratique Poplaire Lao: 280-287; Malaysia - Malaisie: 295-310; Myanmar: 388-352; Philippines: 434-449; Singapore - Singapour: 492-506; Thailand: 541-556; Viet Nam: 613-622)

The World of Learning (1999). 1998. 49th ed. Europa Pub. Ltd., London, (Brunei: 205; Indonesia: 738-740; Laos: 983; Malaysia: 1006-1008; Myanmar: 1054; Philippines: 1154-1155; Singapore: 1326; Thailand: 1465-1466; Viet Nam: 1950-1952).

Yit, C.C. (2000) Development of libraries of the Congress of Southeast Asian Librarians (CONSAL): 1996 to 1999 , 
MSc Dissertation, Nanyang Technological University, Singapore

$\underline{\text { top of page }}$

\section{Appendix}

The Appendix shows the questionnaire used for the survey. Repeated information is eliminated to save space. Areas in which survey returns were found particularly lacking are shown by an $\left(^{*}\right)$ next to the Table heading.

Pre-Survey Information:

(1) The following information provided in the survey would cover the Country :

(2) The contact person for clarification (if any) is :

Name:

Address:

Phone:

Fax:

Email:

(3) Any other useful information about the survey (e.g. Data for year of 1999 is correct up to the month of September 1999)

\section{Part 1: Physical Development}

Table 1.1 Types and Number of Libraries

(Our interest is in the number of libraries that are physically distinct. For example, National Libraries may have various branches or operate at different states)

\begin{tabular}{|c|c|c|c|}
\hline Type of Libraries & 1996 & $\ldots$. & 1999 \\
\hline \multicolumn{4}{|l|}{ National } \\
\hline \multicolumn{4}{|l|}{ Main } \\
\hline \multicolumn{4}{|l|}{ Branches } \\
\hline \multicolumn{4}{|l|}{ Public } \\
\hline \multicolumn{4}{|c|}{ State/ Provincial/ Regional } \\
\hline \multicolumn{4}{|c|}{ Community/ Village/ Town } \\
\hline \multicolumn{4}{|l|}{ Children's } \\
\hline \multicolumn{4}{|l|}{ Mobile } \\
\hline \multicolumn{4}{|l|}{ Academic } \\
\hline \multicolumn{4}{|c|}{ University and Institutions } \\
\hline \multicolumn{4}{|l|}{ Schools } \\
\hline \multicolumn{4}{|l|}{ Special } \\
\hline \multicolumn{4}{|l|}{ Ministry/ Government } \\
\hline \multicolumn{4}{|l|}{ Private/ Commercial } \\
\hline \multicolumn{4}{|l|}{ Others (Please specify) } \\
\hline 1. & & & \\
\hline
\end{tabular}

Table 1.2 Size and Floor Space Allocation of Libraries * 
(Our interest is in the changes in floor space allocation for specific purposes in terms of percentage of total built-up area for the libraries. The key figures required would be the National Library, but if figures for Public Libraries (average) and others could be available, it would be most beneficial)

\begin{tabular}{|c|c|c|}
\hline Type of Libraries & 1996 & \begin{tabular}{l|l}
$\ldots$ & 1999
\end{tabular} \\
\hline \multicolumn{3}{|l|}{ National } \\
\hline \multicolumn{3}{|l|}{ Built up area (in sq. m.) } \\
\hline \multicolumn{3}{|l|}{ Shelves area (as $\%$ of built up area) } \\
\hline \multicolumn{3}{|l|}{ Storage area (as $\%$ of built up area) } \\
\hline \multicolumn{3}{|l|}{ Office area (as $\%$ of built up area) } \\
\hline \multicolumn{3}{|l|}{ Public area (as $\%$ of built up area) } \\
\hline \multicolumn{3}{|c|}{ Public (Regional level and above, if available) } \\
\hline \multicolumn{3}{|l|}{ Built up area (average in sq. m.) } \\
\hline \multicolumn{3}{|l|}{ Shelves area (as $\%$ of built up area) } \\
\hline \multicolumn{3}{|l|}{ Storage area (as $\%$ of built up area) } \\
\hline \multicolumn{3}{|l|}{ Office area (as $\%$ of built up area) } \\
\hline \multicolumn{3}{|l|}{ Public area (as $\%$ of built up area) } \\
\hline \multicolumn{3}{|l|}{ Others (if available) } \\
\hline \multicolumn{3}{|l|}{ Built up area (average in sq. m.) } \\
\hline \multicolumn{3}{|l|}{ Shelves area (as $\%$ of built up area) } \\
\hline \multicolumn{3}{|l|}{ Storage area (as $\%$ of built up area) } \\
\hline \multicolumn{3}{|l|}{ Office area (as \% of built up area) } \\
\hline Public area (as \% of built up area) & & \\
\hline
\end{tabular}

Table 1.3 Location and Distribution of National and Public Libraries Compared to Population Centres. *

(Our interest is in the average target population supported by each library, as we progress to larger size population centres, the number of libraries should accumulate and ultimately add up to your country's total. As not all categories would be applicable to your country, please use the population centre breakdown that is commonly used by your country, replacing the headings if necessary)

\begin{tabular}{|l|l|l|l|}
\hline Type of Population Centre & 1996 & $\ldots$ & 1999 \\
\hline Village or Neighbourhood & & & \\
\hline Number of Libraries $\left(^{*}\right)$ & & & \\
\hline Average Population served & & & \\
\hline
\end{tabular}




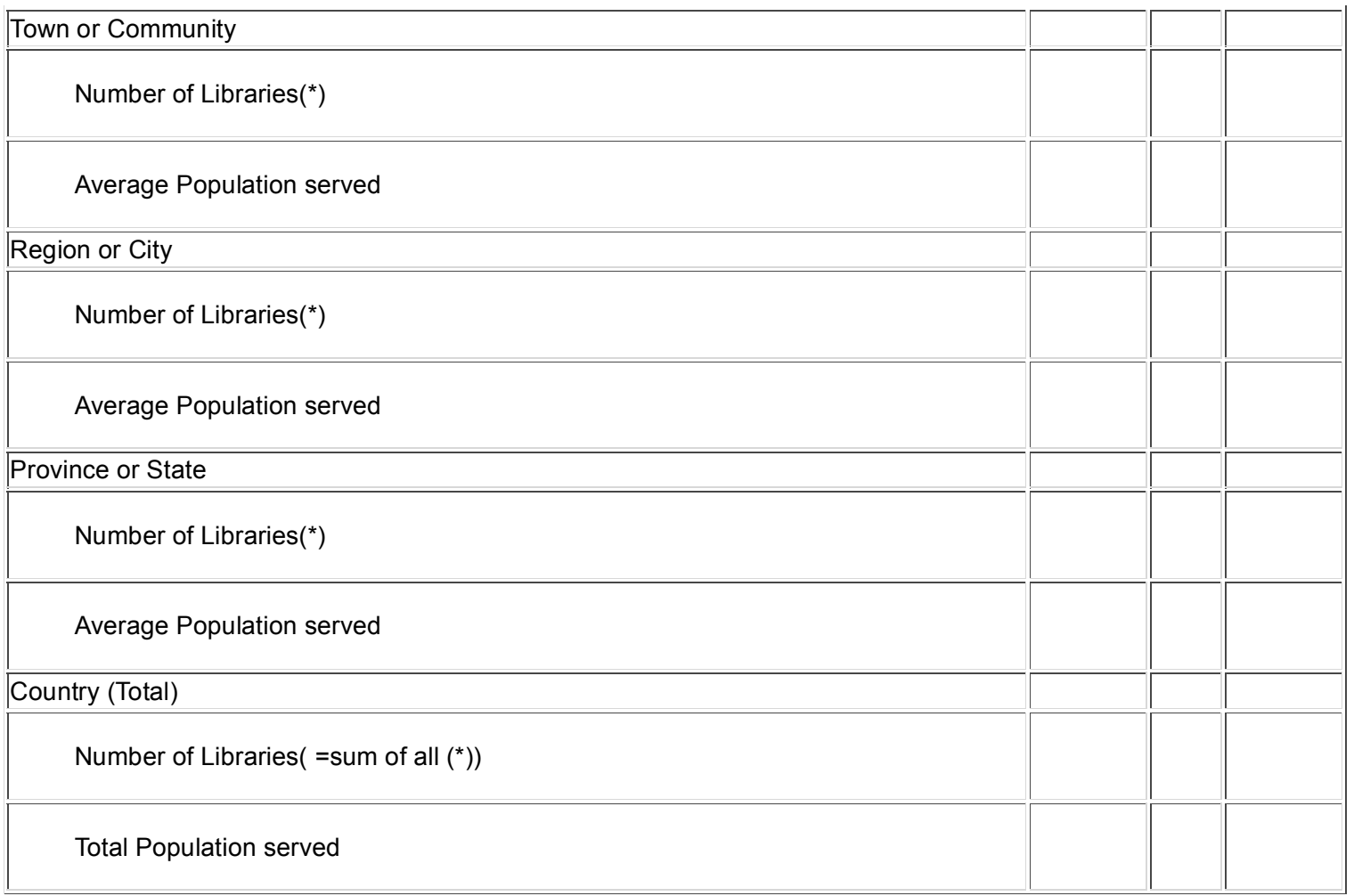

\section{Part 2: Standards Development}

Table 2.1 Standards Used in Country

(For standards, we are interested in the proportion of libraries within your country using or adopting standards, or forms of practices that are applicable to the various aspects of library work. Please express the findings as \% of total libraries within your country)

\begin{tabular}{|c|c|c|c|}
\hline Aspect of Library Work & 1996 & $\ldots$ & 1999 \\
\hline \multicolumn{4}{|l|}{ Bibliographic } \\
\hline \multicolumn{4}{|l|}{ AACR } \\
\hline \multicolumn{4}{|l|}{ LCSH } \\
\hline \multicolumn{4}{|l|}{ Others: } \\
\hline \multicolumn{4}{|l|}{ Classification } \\
\hline \multicolumn{4}{|l|}{$\mathrm{DDC}$} \\
\hline \multicolumn{4}{|l|}{ LC } \\
\hline \multicolumn{4}{|l|}{ UDC } \\
\hline \multicolumn{4}{|l|}{ Subject } \\
\hline \multicolumn{4}{|l|}{ Others: } \\
\hline \multicolumn{4}{|l|}{ Forms of Catalogs } \\
\hline Book & & & \\
\hline
\end{tabular}




\begin{tabular}{|c|c|c|c|}
\hline Card & & & \\
\hline Microform & & & \\
\hline Electronic - In-house & & & \\
\hline Electronic - Web-based & & & \\
\hline Others: & & & \\
\hline Information Exchange & & & \\
\hline ISBN & & & \\
\hline \hline ISSN & & & \\
\hline MARC & & & \\
\hline Other aspects (please define) & & & \\
\hline 1. & & & \\
\hline \hline
\end{tabular}

\section{Part 3: Systems Development}

Table 3.1 Types of Systems Used in Country

(For systems development, our interest is in the proportion of libraries within your country that are using different modes of operation to run their libraries. Please report figures as \% of total libraries within your country)

\begin{tabular}{|c|c|c|c|}
\hline Type of Library Operating System & 1996 & $\ldots$ & 1999 \\
\hline \multicolumn{4}{|l|}{ Acquisition } \\
\hline \multicolumn{4}{|l|}{ Manual } \\
\hline \multicolumn{4}{|l|}{ Semi-automated } \\
\hline \multicolumn{4}{|l|}{ Automated } \\
\hline \multicolumn{4}{|l|}{ Cataloging } \\
\hline \multicolumn{4}{|l|}{ Manual } \\
\hline \multicolumn{4}{|l|}{ Semi-automated } \\
\hline \multicolumn{4}{|l|}{ Automated } \\
\hline \multicolumn{4}{|l|}{ Circulation } \\
\hline \multicolumn{4}{|l|}{ Manual } \\
\hline Semi-automated & & & \\
\hline
\end{tabular}




\begin{tabular}{|l|l|l|l|}
\hline \multicolumn{1}{|c|}{ Automated } & & \\
\hline Integrated System & & \\
\hline Networked to other libraries within country & & \\
\hline Networked to other libraries outside country & & \\
\hline
\end{tabular}

Table 3.2 List of Top 3 Supplier of Library Systems in Country *

1.

2.

3.

Part 4: Staff Development

Note: This part of the survey onwards refers to data pertaining to your own National Libraries (and/or Public Libraries if applicable)

Table 4.1 Number of Employed Staff (Breakdown by Training)

(Our interest is in the population of library trained professionals occupying various staff positions in the Library)

\begin{tabular}{|c|c|c|c|}
\hline Staff Position & 1996 & $\ldots$ & 1999 \\
\hline \multicolumn{4}{|l|}{ Directors and above } \\
\hline \multicolumn{4}{|l|}{ Library Professional } \\
\hline \multicolumn{4}{|l|}{ Non-Library Professional } \\
\hline \multicolumn{4}{|l|}{ Managers and above } \\
\hline \multicolumn{4}{|l|}{ Library Professional } \\
\hline \multicolumn{4}{|l|}{ Non-Library Professional } \\
\hline \multicolumn{4}{|c|}{ Librarians or Library Executive Officers } \\
\hline \multicolumn{4}{|l|}{ Library Professional } \\
\hline \multicolumn{4}{|l|}{ Non-Library Professional } \\
\hline \multicolumn{4}{|l|}{ Library Support Staff } \\
\hline \multicolumn{4}{|l|}{ Para-Professional } \\
\hline \multicolumn{4}{|l|}{ Non-Professional } \\
\hline \multicolumn{4}{|l|}{ Other Staff Types } \\
\hline \multicolumn{4}{|l|}{ Library Professional } \\
\hline Non-Library Professional & & & \\
\hline
\end{tabular}

Table 4.2 Number of Employed Staff (Breakdown by Place of Training)

(Our interest is in the place where the staff working in the library has been trained)

\begin{tabular}{|c||c|c|c|}
\hline Staff Type & 1996 & $\ldots$. & 1999 \\
\hline Professional & & & \\
\hline Local & & & \\
\hline
\end{tabular}




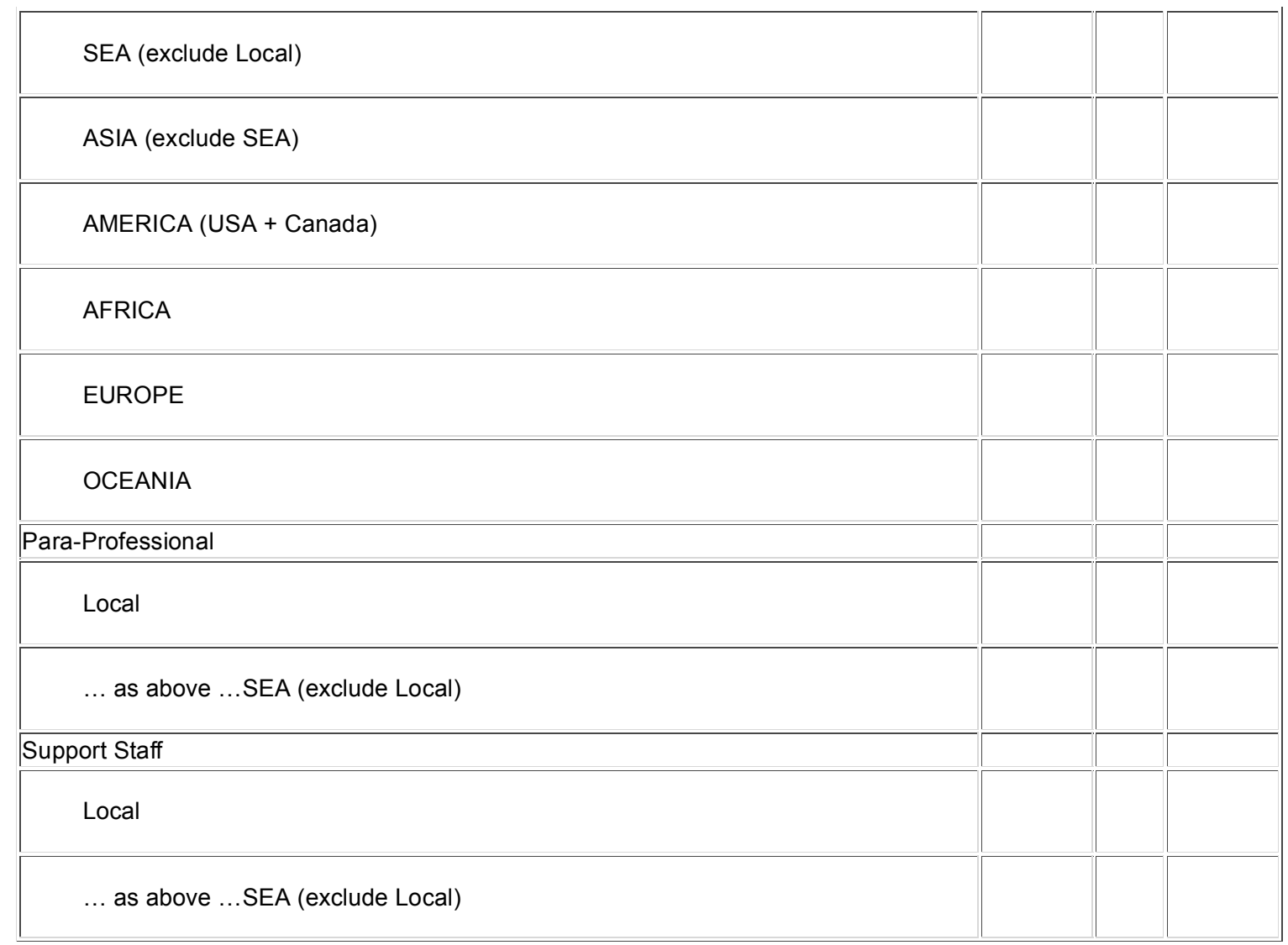

Table 4.3 Breakdown of Length of Years of Service of Library Staff

\begin{tabular}{|l|l|l|l|}
\hline Years of Service & & \\
\hline Less than 2 years & & & \\
\hline Between 2 to 5 years & & & \\
\hline Between 5 to 10 years & & & \\
\hline Between 10 to 20 years & & & \\
\hline More than 20 years & & & \\
\hline
\end{tabular}

Table 4.4 Number of Professionals by Library Work Roles

(Our interest is in the various roles taken up by trained Library Professionals in Libraries)

\begin{tabular}{|l|l|l|l|l|}
\hline Work Roles & 1996 & 1999 \\
\hline Acquisition & & & \\
\hline Administration & & & \\
\hline Archival & & & & \\
\hline Cataloging & & & & \\
\hline Circulation & & & & \\
\hline Indexing & & & & \\
\hline Systems & & & \\
\hline Research & & & \\
\hline Training & & & \\
\hline Others (please define):
\end{tabular}

Table 4.5 Staff Exchange Programs and Conference Attendance

(Our interest is in the number of staff who have gone for attachments, visits and conferences within the years stated)

Type of programs

Staff attachments

1996

\begin{tabular}{|l|l|}
\hline$\ldots$ & 1999 \\
\hline &
\end{tabular}




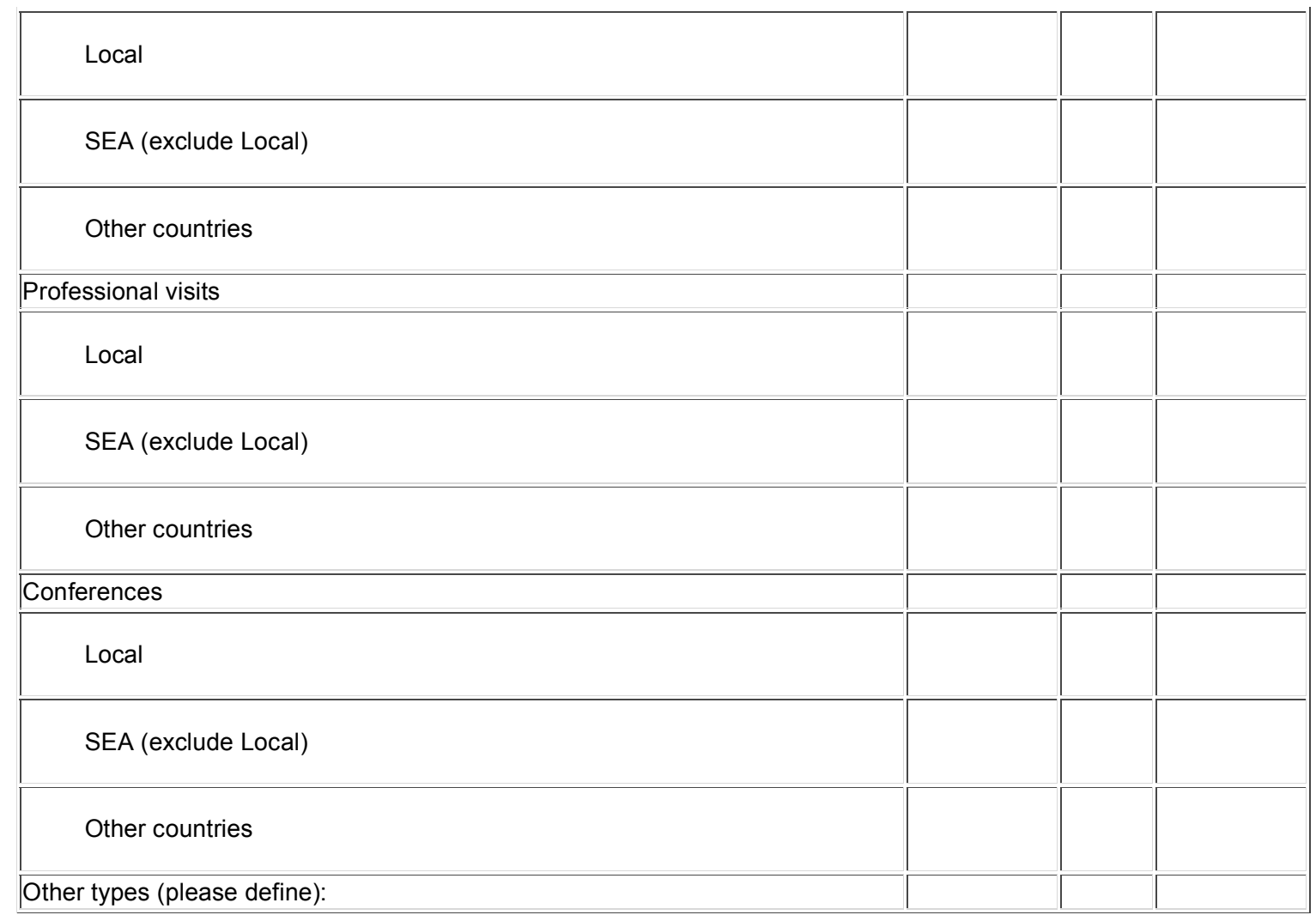

\section{Part 5: Collection Development}

Table 5.1 Deposition of National Publications

(Our interest is in the estimated percentage of the various forms of national publications deposited with the library)

\begin{tabular}{|l|l|l|l|l|}
\hline Type of publication & 1996 & & \\
\hline Print & & & \\
\hline Books & & & \\
\hline Periodicals & & & \\
\hline Others: & & & \\
\hline Non-Print & & & \\
\hline \hline Audio-visuals & & \\
\hline Digital or Web-based & & \\
\hline Others: & & \\
\hline
\end{tabular}

Table 5.2 Collection Mix (Breakdown by Language)

\begin{tabular}{|c|c|c|c|}
\hline Language & 1997 & $\cdots$ & 1999 \\
\hline \multicolumn{4}{|c|}{ National (please indicate) } \\
\hline \multicolumn{4}{|l|}{ English } \\
\hline Others: & & & \\
\hline
\end{tabular}

Table 5.3 Collection Mix (Breakdown by Age Group)

(Our interest is in the way your Library define the age groups and the volume of collected items within your library targeted for them) 


\begin{tabular}{|c|c|c|c|}
\hline Age Groups & 1996 & $\ldots$ & 1999 \\
\hline Children ( less then __ years old) & & & \\
\hline Youth (Between __ and __ years old) & & & \\
\hline Adults (Between __ and ___ years old) & & & \\
\hline Retirees (More than __ years old) & & & \\
\hline
\end{tabular}

Table 5.4 Collection Mix (Breakdown by Accessibility)

(Our interest is in the number of items accessible through the defined means below)

\begin{tabular}{|c|c|c|c|}
\hline Accessibility type & 1996 & $\ldots$ & 1999 \\
\hline \multicolumn{4}{|l|}{ Reference } \\
\hline \multicolumn{4}{|l|}{ Print } \\
\hline \multicolumn{4}{|l|}{ Non-print (physical items) } \\
\hline \multicolumn{4}{|l|}{ Non-print (digital or online access) } \\
\hline \multicolumn{4}{|l|}{ Lending } \\
\hline \multicolumn{4}{|l|}{ Print } \\
\hline \multicolumn{4}{|l|}{ Non-print (physical items) } \\
\hline \multicolumn{4}{|l|}{ Non-print (digital or online access) } \\
\hline \multicolumn{4}{|l|}{ Total } \\
\hline \multicolumn{4}{|l|}{ Print } \\
\hline \multicolumn{4}{|l|}{ Non-print (physical items) } \\
\hline Non-print (digital or online access) & & & \\
\hline
\end{tabular}

Table 5.5 Collection Mix (Volumes Breakdown by Subjects)

(Our interest is in the changes in the volumes of collected items within the library in accordance to your library adopted subject breakdown. Please expand the table where appropriate)

\begin{tabular}{|c|c|c|c|}
\hline $\begin{array}{l}\text { Classification Type(please tick one per category and complete the classification code, } \\
\text { if necessary) }\end{array}$ & Coverage & 1997 & .... 1999 \\
\hline DDC: 000-099 & Heritage & & \\
\hline LC: & Local & & \\
\hline UDC: & SEA & & \\
\hline Others: & $\begin{array}{l}\text { Other } \\
\text { Countries }\end{array}$ & & \\
\hline DDC:100-199 & Heritage & & \\
\hline LC: & Local & & \\
\hline UDC: & SEA & & \\
\hline Others: & $\begin{array}{l}\text { Other } \\
\text { Countries }\end{array}$ & & \\
\hline Similarly for: DDC:200-299 & Heritage & & \\
\hline DDC:300-399 & Heritage & & \\
\hline DDC:400-499 & Heritage & & \\
\hline DDC:500-599 & Heritage & & \\
\hline DDC:600-699 & Heritage & & \\
\hline
\end{tabular}




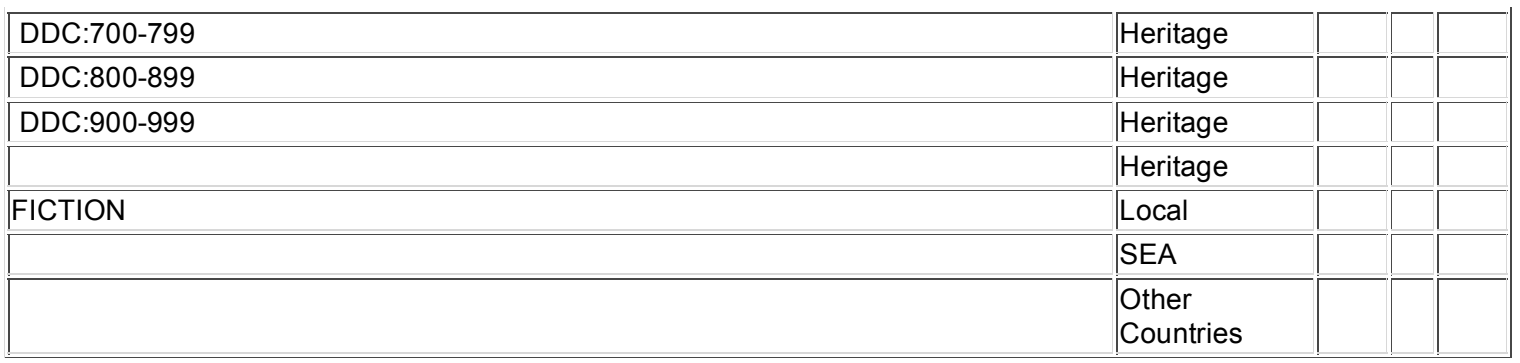

\section{Part 6: User Development}

Table 6.1 Membership and Loans (by Age Group as Against Population)

(The age group breakdown would follow that as defined by your library in Part 5. Our interest is in estimated \% of population registered as members)

\begin{tabular}{|c|c|c|}
\hline Age Group (please define as appropriate) & 1996 & 1999 \\
\hline Children ( less then __ years old) & & \\
\hline \multicolumn{3}{|l|}{ Number of registered members } \\
\hline \multicolumn{3}{|l|}{ Children population } \\
\hline \multicolumn{3}{|l|}{ Loans } \\
\hline \multicolumn{3}{|l|}{ Youth (Between ___ and __ years old) } \\
\hline \multicolumn{3}{|l|}{ Number of registered members } \\
\hline \multicolumn{3}{|l|}{ Youth population } \\
\hline \multicolumn{3}{|l|}{ Loans } \\
\hline \multicolumn{3}{|l|}{ Adults (Between ___ and ___ years old) } \\
\hline \multicolumn{3}{|l|}{ Number of registered members } \\
\hline \multicolumn{3}{|l|}{ Adult population } \\
\hline \multicolumn{3}{|l|}{ Loans } \\
\hline \multicolumn{3}{|l|}{ Retirees (More than __ years old) } \\
\hline \multicolumn{3}{|l|}{ Number of registered members } \\
\hline \multicolumn{3}{|l|}{ Retiree population } \\
\hline \multicolumn{3}{|l|}{ Loans } \\
\hline \multicolumn{3}{|l|}{ Total } \\
\hline \multicolumn{3}{|l|}{ Number of registered members } \\
\hline \multicolumn{3}{|l|}{ Total population } \\
\hline Loans & & \\
\hline
\end{tabular}


Table 6.2 Membership and Loans (by Sex as Against Population)

\begin{tabular}{|l|l|l|l|l|}
\hline Sex & 1996 & $\ldots$ & 1999 \\
\hline Male & & & \\
\hline Number of registered members & & & \\
\hline Lale population & & & \\
\hline Loans & & & \\
\hline \hline Number of registered members & & & \\
\hline \hline Female population & & & \\
\hline Loans & & \\
\hline
\end{tabular}

Table 6.3 Enquiries Handled

(Our interest is in the number of users' enquiries handled by your library)

Types

Simple (e.g. Directional or Quick reference)

Complex (e.g. Research or assistance from other libraries required)

Incomplete (e.g. no answers available or retrievable within user required time-frame for response)

Total

Table 6.4 User Feedback

(Our interest is in the amount of user feedback received to gauge user expectation of services in libraries)

\begin{tabular}{|l|l|l|l|}
\hline Types & 1996 & $\ldots$ & 1999 \\
\hline Compliments & & & \\
\hline Complaints & & & \\
\hline Suggestions & & & \\
\hline
\end{tabular}

Table 6.5 User Education and Programs

(Our interest is in the attendance for library organized programs for users)

\begin{tabular}{|l|l|l|l|}
\hline Types & 1996 & & 1999 \\
\hline User Education/Training & & & \\
\hline Story Telling & & & \\
\hline Talks & & & \\
\hline Workshops & & & \\
\hline Other programs (please define): & & \\
\hline
\end{tabular}

\section{Part 7: Research Development}

Table 7.1 Number of User Studies done

(Our interest is in the number of user studies conducted by your library over the specified time period. User studies include Surveys, Statistical Analysis, Interviews, Focus Group Sessions, Passive Observation, and so on.)

\begin{tabular}{|l|l||l|l|}
\hline & 1996 & $\ldots$ & 1999 \\
\hline Number of User Studies conducted in & & & \\
\hline
\end{tabular}

Table 7.2 Library-related Research Publications

(Our interest is in the volume of publication generated by your library within the specified period. For other type of publication that is not defined, please expand table if required.) 


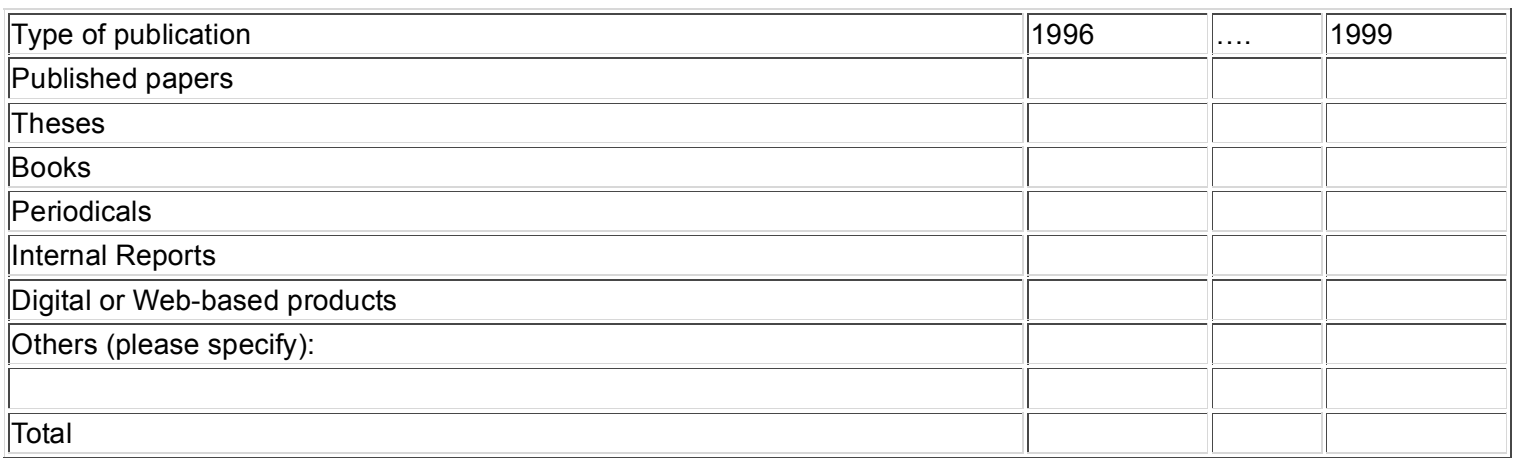

\section{Part 8: Special Development}

Please list any special projects that you wish to be highlighted as part of your library development, for example, your library has initiated a new database resource sharing program with a foreign library to improve access to information for your users.

(Note: The inputs in this Part should only encompass projects or special development from the year 1996 onwards)

Name of Program :

Year Started :

Description :

- End of Questionnaire -

$\underline{\text { top of page }}$ 